\title{
HUBUNGAN KEBIASAAN SARAPAN PAGI DAN STATUS GIZI \\ TERHADAP PRESTASI BELAJAR SISWA DI SDN 58 INPRES \\ PANGALE KELURAHAN LEMBANG KABUPATEN MAJENE
}

\author{
Yuliana Sulaiman ${ }^{1}$ \\ Prodi Diploma Keperawatan STIKES Bina Bangsa Majene ${ }^{1}$ \\ Email : yulianahsulaiman31@gmail.com
}

\begin{abstract}
ABSTRAK
Prestasi belajar adalah hasil yang dicapai sebaik-baiknya menurut kemampuan pada waktu tertentu terhadap hal - hal yang dikerjakan atau dilakukan. Penelitian ini bertujuan untuk mengetahui hubungan kebiasaan sarapan pagi dan status gizi terhadap prestasi belajar siswa di SDN 58 Inpres Pangale. Jenis penelitian adalah penelitian survey analitik dengan pendekatan cross sectional study. Populasi dalam penelitian adalah semua siswa kelas IV,V dan VI di SDN Inpres Pangale. Sampel dalam penelitian sebanyak 51 siswa. Teknik analisa data menggunakan uji statistik Chi square untuk mengetahui hubungan kebiasaan sarapan pagi dan status gizi terhadap prestasi belajar siswa. Hasil analisis bivariat distribusi responden berdasarkan kebiasaan sarapan pagi yang rutin dengan jumlah $29(56,9 \%)$. Disrtibusi responden berdasarkan status gizi yang normal sebanyak $32(62.7 \%)$. Distribusi responden berdasarkan prestasi belajar yang baik sebanyak 28 (54.9\%). Berdasarkan hasil analisis statistik diketahui bahwa tidak ada hubungan antara kebiasaan sarapan pagi dengan prestasi belajar siswa di SDN 58 Inpres Pangale diperoleh nilai $p=0.14$ dengan taraf signifikan $\alpha=0,05$, yang berarti $\mathrm{p}>\alpha$, dan tidak ada hubungan antara status gizi dengan prestasi belajar siswa di SDN 58 Inpres Pangale diperoleh nilai $\mathrm{p}=0.97$ dengan taraf signifikan $\alpha=0,05$, yang berarti $\mathrm{p}>\alpha$. Disimpulkan bawa tidak ada hubungan antara kebiasaan sarapan pagi dan status gizi terhadap prestasi belajar siswa di SDN 58 Inpres pangale. Disarankan kepada ibu atau orang tua siswa agar selalu memperhatikan dan mendorong anaknya untuk meningkatkan cara belajar sehingga prestasi anak bisa selalu meningkat dan selalu membiasakan sarapan pagi sebelum pergi kesekolah agar status gizi siswa selalu normal.
\end{abstract}

Kata Kunci : Prestasi Belajar, Status Gizi, Kebiasaan Sarapan Pagi 
PENDAHULUAN

Kelompok anak sekolah merupakan salah satu segmen penting di masyarakat dalam upaya peningkatan pemahaman dan kesadaran gizi sejak dini. Anak sekolah merupakan sasaran strategi dalam perbaikan gizi masyarakat dan merupakan generasi penerus tumpuan bangsa sehingga perlu disiapkan dengan baik kualitasnya. Kemenkes RI masih giat dalam upaya penanggulangan masalah kesehatan anak usia sekolah di Indonesia. Dua masalah utama yang jadi fokus utama ialah kurangnya makan sayur pada usia sekolah dan buah, dan perilaku mencuci tangan agar bisa mencegah penyakit (Yudesti \& Nawawi 2013).

Pada usia sekolah anak sudah mulai lepas dari pengawasan orang tua dan bergaul dengan teman sekolahnya. Masa ini juga sangat memerlukan perhatian terutama dalam hal membiasakan sarapan pagi sebelum ke sekolah, memilih jajanan sehat di sekolah dan agar selalu mengevaluasi status gizi anak. (Devi disitasi sarimin 2016). Pentingnya sarapan pagi bagi prestasi akademik tercermin dari efek sarapan terhadap fungsi kognigtif. Beberapa penelitian mengungkapkan bahwa melewatkan sarapan pagi berpengaruh buruk terhadap kemampuan memecahkan masalah, memori jangka pendek dan pemusatan perhatian, aritmatika, tugas-tugas memecahkan masalah dan penalaran (Depkes RI disitasi sarimin 2016).

Permasalahan gizi dapat mempengaruhi pertumbuhan serta perkembangan anak terutama pada anak usia sekolah dasar. Berdasarkan World Health Organization (WHO) tahun 2011 memperkirakan bahwa 54 persen kematian anak disebabkan oleh keadaan gizi yang buruk. Berdasarkan hasil Pemantauan Status Gizi (PSG) di Sulawesi Barat Tahun 2017 Tinggi badan menurut umur (TB/U), prevalensi pada anak umur 5-12 tahun yang pendek sebesar $19.4 \%$ dan sangat sangat pendek $8.3 \%$.

Menurut Nadharatunna'im disitasi Muclis 2015 terdapat hubungan yang signifikan antara status gizi dengan prestasi belajar didapatkan bahwa murid yang berstatus gizi kurang dengan prestasi belajar kurang berjumlah 13 orang $(29,5 \%)$ dan yang berprestasi belajar baik dengan status gizi kurang berjumlah 6 orang $(13,6 \%)$, sedangkan murid dengan status gizi cukup dengan prestasi belajar kurang berjumlah 7 orang $(15,9 \%)$ dan prestasi belajar baik dengan status gizi cukup berjumlah 18 orang $(40,9 \%)$.

\section{BAHAN DAN METODE}

\section{Lokasi dan Rancangan Penelitian}

Penelitian ini dilaksanakan di SDN No.58 Inpres Pangale Kecamatan Banggae Timur Kelurahan Lembang Kabupaten Majene. Waktu Tanggal 16-19 Juli 2018.

Jenis penelitian yang digunakan dalam penelitian ini adalah survey analitik dengan pendekatan "Cross Sectional" yaitu hubungan antara variabel independen 
dengan variabel dependen dikaji pada saat yang bersamaan untuk mengetahui apakah ada Hubungan Kebiasaan Sarapan Pagi dan Status Gizi Dengan Prestasi Belajar Siswa di SDN 58 Inpres Pangale Kelurahan Lembang Kecamatan Banggae Timur Kabupaten Majene.

\section{Populasi dan Sampel}

Populasi dalam penelitian ini adalah seluruh siswa II, III, IV, V dan VI di SDN No.58 Inpres Pangale Kelurahan Lembang Kecamatan Banggae Timur Kabupaten Majene sebanyak 103 siswa. Sampel dalam penelitian ini adalah semua siswa di SDN 58 Inpres Pangale sebanyak 51 siswa.

\section{Pengumpulan Data}

Data primer dalam penelitian ini adalah data kebiasaan sarapan pagi dan status gizi semua murid kelas 2,3,4,5 dan 6 sebanyak 51 siswa yang ada di SDN 58 pangale. Untuk memperoleh data ini dilakukan wawancara dan pengukuran TB kepada responden

\section{Analisis Data}

Analisis bivariat yang digunakan dalam penelitian ini yaitu uji chi square dengan nilai $\alpha=0,05 \%$ dengan menggunakan program spss untuk mengetahui ada tidaknya hubungan kebiasaan sarapan pagi dengan prestasi belajar dan status gizi dengan prestasi belajar pada siswa SDN 58 Inpres pangale.

\section{PEMBAHASAN}

Hasil analisis statistik dengan menggunakan uji Chi Square pada penelitian ini diperoleh nilai $\mathrm{p}=$ 0,096 dengan taraf signifikan $\alpha=0,05$, yang berarti $\mathrm{p}>\alpha$, hal ini menunjukkan $\mathrm{H}_{0}$ diterima atau $\mathrm{Ha}_{\mathrm{a}}$ ditolak, dengan demikian tidak ada hubungan antara kebiasaan sarapan pagi dengan prestasi belajar siswa di SDN 58 Inpres Pangale.

Hasil analisis statistik dengan menggunakan uji Chi Square pada penelitian ini diperoleh nilai $\mathrm{p}=0,97$ dengan taraf signifikan $\alpha=0,05$, yang berarti $\mathrm{p}>\alpha$, hal ini menunjukkan $\mathrm{H}_{0}$ diterima atau $\mathrm{H}_{\mathrm{a}}$ ditolak. Dengan demikian tidak ada hubungan antara status gizi dengan prestasi belajar siswa di SDN 58 Inpres Pangale.

\section{KESIMPULAN}

Tidak ada hubungan kebiasaan sarapan pagi dengan prestasi belajar siswa di SDN 58 Inpres Pangale Kel. Lembang Kab. Majene Tahun 2018. Tidak ada hubungan status gizi dengan prestasi belajar siswa di SDN 58 Inpres Pangale Kel. Lembang Kab. Majene Tahun 2018. Adapun saran yang bisa di ambil adalah diharapkan ibu atau orang tua siswa agar selalu memperhatikan dan mendorong anaknya untuk meningkatkan cara belajar sehingga prestasi anak bisa selalu meningkat. Diharapkan kepada siswa agar selalu membiasakan sarapan pagi sebelum pergi kesekolah agar status gizi siswa selalu normal. Diharapkan kepada pihak sekolah agar selalu memeperhatikan siswa-siswanya dengan memberikan motivasi seperti selalu mengingatkan bahwa sarapan pagi sangat berguna bagi kesehatan kita. 


\section{DAFTAR PUSTAKA}

Agustina L. 2011 Pengaruh motivasi belajar siswa terhadap pestasi belajar ipa di sekolah dasar.

Fitriana. 2014. hubungan kebiasaan sarapan pagi, status gizi, pendidikan ibu dengan Prestasi Belajar Murid SDN nomor 28 Inpres Puttada Kecamatan Sendana Kabupaten Majene.

Irwanti. L. 2015. Penentuan Status Gizi Secara Tidak Langsung (Pengukuran

FaktorEkologi).https://leilyairwa nti.wordpress.com/2015/06/02/ penentuan-status-gizi-secaratidak-langsung-pengukuranfaktor-ekologi

Maleke. V dan Umboh. A. 2016 Hubungan Status Gizi Dengan Prestasi Belajar Siswa Sekolah Dasar Di Kecamatan Modoinding (Jurnal e-Clinic (eCl), Volume 3, Nomor 3, September-Desember 2015).

Muchlis 2015. Hubungan status gizi dengan prestasi belajar siswa sekolah dasar negeri 063 di pesisir sungai siak kecamatan rumbai pesisir kota pekanbaru. https://media.neliti.com/media/p ublications/187029-IDhubungan-status-gizi-denganprestasi-bel.pdf

Nurfadilah.AM. 2014. Faktor-faktor yang berhubungan dengan Prestasi Belajar pada anak SD kalas IV dan V di SDN 063 Inpres Lagiagi Kabupaten Polewali Mandar.
Nisaka.Z.Y. 2017Faktor-faktor apa yang mempengaruhi Status Gizi pada manusia https://www.dictio.id/t/faktorfaktor-apa-yang-mempengaruhistatus-gizi-pada-manusia/12061

Pratiwi 2010, Hubungan status gizi dengan prestasi belajar siswa SDN.No.22 kalukuang kecamatan binamu kabupaten jeneponto tahun 2010. Makassar

Sarimin.S, 2016. Hubungan pengetahuan tentang sarapan pagi dengan prestasi belajar anak di sd inpres talikuran kecamatan kawangkoan utara. e-jurnal keperawatan (eKp) volume 4 nomor 1. Mei 2016.

Supariasa 2012. Penilaian status gizi. Edisi revisi. Jakarta.

Sutarno 2014. Makalah gizi anak usia sekolah http://andriyansutarno.co.id/201 4/06/makalah-gizi-anak-usia sekolah.html

Tim Dosen Stikes BBM.2018. Panduan Penyusunan Skripsi, Program Studi Kesehatan Masyarakat, Majene: Prodi Kesmas Stikes BBM.

Tumiwa , E.S dan Sarimin. S. 2016. Hubungan Pengetahuan Tentang Sarapan Pagi Dengan Prestasi Belajar Anak Di Sd Inpres Talikuran Kecamatan Kawangkoan Utara. (e-jurnal keperawatan (eKp) volume 4 nomor 1. Mei 2016). 